\title{
Asthma Trends in Mississippi Coastal Region with Air Pollutants and Meteorological Factors
}

\section{Tuluri F'* and Gorai $\mathrm{AK}^{2}$}

${ }^{1}$ Department of Industrial Systems \& Technology, J ackson State University, USA

${ }^{2}$ Department of Mining Engineering, National Institute of Technology, India

*Corresponding author: Tuluri F, Department of Industrial Systems \& Technology, J ackson State University, USA

Received: November 28, 2016; Accepted: J anuary 12, 2017; Published: January 19, 2017

\begin{abstract}
An understanding of interplay between asthma, criteria air pollutants, and meteorological factors is essential to predicting human health and reducing the capital costs on controlling asthma prevalence. A systematic relationship between asthma and variables related to air quality and weather in a location will help mitigate or reduce impact of asthma over the people in it. The impact of industries, transportation, and weather on health is complex and needs continuous monitoring for controlling health disorders. The present study examines Poisson Regression Model of the daily data of asthma admissions, Particulate Matter $\left(\mathrm{PM}_{25}\right)$, Ozone $\left(\mathrm{O}_{3}\right)$, Nitrogen dioxide $\left(\mathrm{NO}_{2}\right)$, temperature, and humidity in selective locations of Mississippi coastal region of Gulf of Mexico for the period 2003 to 2011. The study region consists of three locations, namely Gulfport, Pascagoula, and Waveland because of the extent of data availability. Overall, the results indicate a negative correlation of asthma with temperature and the effect was statistically significant $(p<0.05)$ in all the regions. The correlation of other variables was not consistent uniformly, and their influence on asthma was not statistically significant except in few cases.
\end{abstract}

Keywords: Poisson Regression Model; Pearson correlation; Asthma; Criteria Pollutants; time series

\section{Introduction}

The inland regions of Gulf of Mexico are affected by industries, and transportation, in addition to extreme weather conditions caused by tropical storms. The increasing industrial activities such as oil and gas production and thermal power plants are drastically affecting the air quality and hence health over the heavily populated neighborhoods of US Gulf coast ranging from Houston to the Louisiana zone [1]. The air quality in these regions is also indirectly affected by the increasing transportation and construction associated with the rapid industrial growth over the US Gulf of Mexico. The weather patterns also play a prominent role in the dispersion of primary and secondary pollutants over the atmosphere to distant places from the sources $[2,3]$.

A survey of literature does show a possibility of linkage of predominant cases of ill-health caused by air pollution in developing as well as developed countries [4-7]. Among other health disorders, asthma prevalence is also considered to be affected by air pollutants, and several research investigations have shown positive association between asthma and air pollution [8-13].

The present work investigates Poisson regression modeling to envisage the relationship between asthma with criteria air pollutants and meteorological parameters over three locations in the Mississippi Gulf coast, namely Gulfport, Pascagoula, and Waveland during the period 2003 to 2011. The locations are selected based on their industrial growth, proximity to the coast, and availability of data. The air pollutants considered are Particulate Matter of diameter less than 2.5 microns $\left(\mathrm{PM}_{2.5}\right)$, Ozone $\left(\mathrm{O}_{3}\right)$, and Nitrogen Oxide $\left(\mathrm{NO}_{2}\right)$; while the meteorological parameters considered are temperature, and humidity.

\section{Materials and Methods}

Consider a random variable $\mathrm{Y}_{\mathrm{t}}$, representing the time series count data $\mathrm{Y}_{1}, \mathrm{Y}_{2}, \ldots ., \mathrm{Y}_{\mathrm{T}}$ and $\mathrm{X}_{\mathrm{i}}$ representing the regression covariate variables, then $Y_{t}$ Poisson distributed over $X$ with a mean value of $\mu$ is given by,

\section{$Y_{t} \sim$ Poisson $\left(\mu_{t}\right)$}

The log linear regression model of Poisson distribution in terms of regression coefficient $(\beta)$ is given by,

$\log \left(\mu_{t}\right)=\beta_{0}+\beta_{1} X_{1}+\beta_{2} X_{2}+\ldots$

In the present situation, $\mathrm{Y}_{\mathrm{t}}$ is the daily counts of asthma admissions at time $t$ and $X_{i}$ the independent variable (for the air pollution and meteorological parameters); the parameter $\beta_{\mathrm{i}}$ represents regression coefficient and is a measure of association between an independent variable, $\mathrm{X}_{\mathrm{i}}$ (for the air pollution and meteorological parameters), and the risk of the outcome Y for the asthma admission. The log linear relationship is given by,

$\log \left(\mu_{t}\right)=\beta_{0}+\beta_{1} O_{3}+\beta_{2} N O_{2}+\beta_{3} P M_{2.5}+\beta_{4}$ temperature $+\beta_{5}$ Humidity

The regression coefficient $\beta_{\mathrm{i}}$ also signifies forecasting proportional change in the value of $Y_{t}$ for a given a unit change in $X_{t}$,

Using SPSS statistical package, the Poisson Regression model is applied to the asthma data without time lag, and analyzed the associations by considering the causes variables individually. This was done to utilize the maximum number of valid datasets.

$$
\begin{aligned}
& \log \left(\mu_{t}\right)=\beta_{0}+\beta_{1} O_{3} \\
& \log \left(\mu_{t}\right)=\beta_{0}+\beta_{1} N O_{2}
\end{aligned}
$$

Austin J Allergy - Volume 4 Issue 1 - 2017

Submit your Manuscript | www.austinpublishinggroup.com

Tuluri et al. ( All rights are reserved
Citation: Tuluri F and Gorai AK. Asthma Trends in Mississippi Coastal Region with Air Pollutants and Meteorological Factors. Austin J Allergy. 2017; 4(1): 1026. 

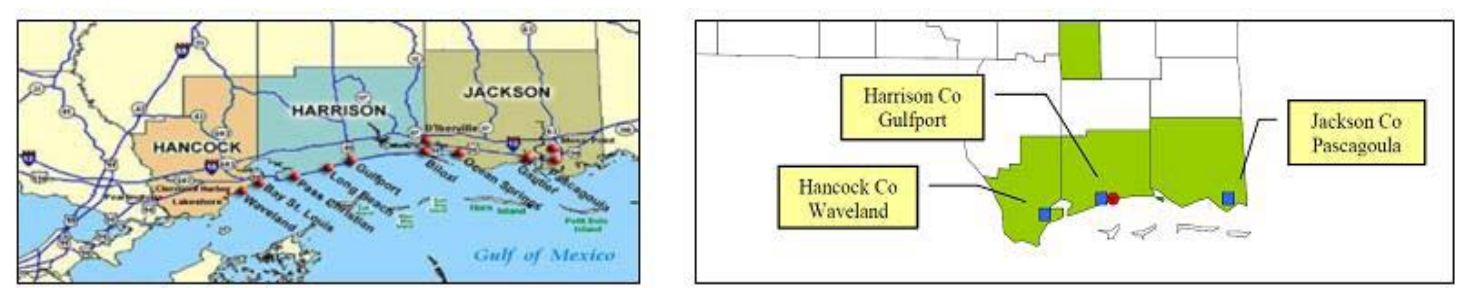

Figure 1: Mississippi Gulf Coast region, and Air Quality Monitors along Mississippi Gulf Coast.

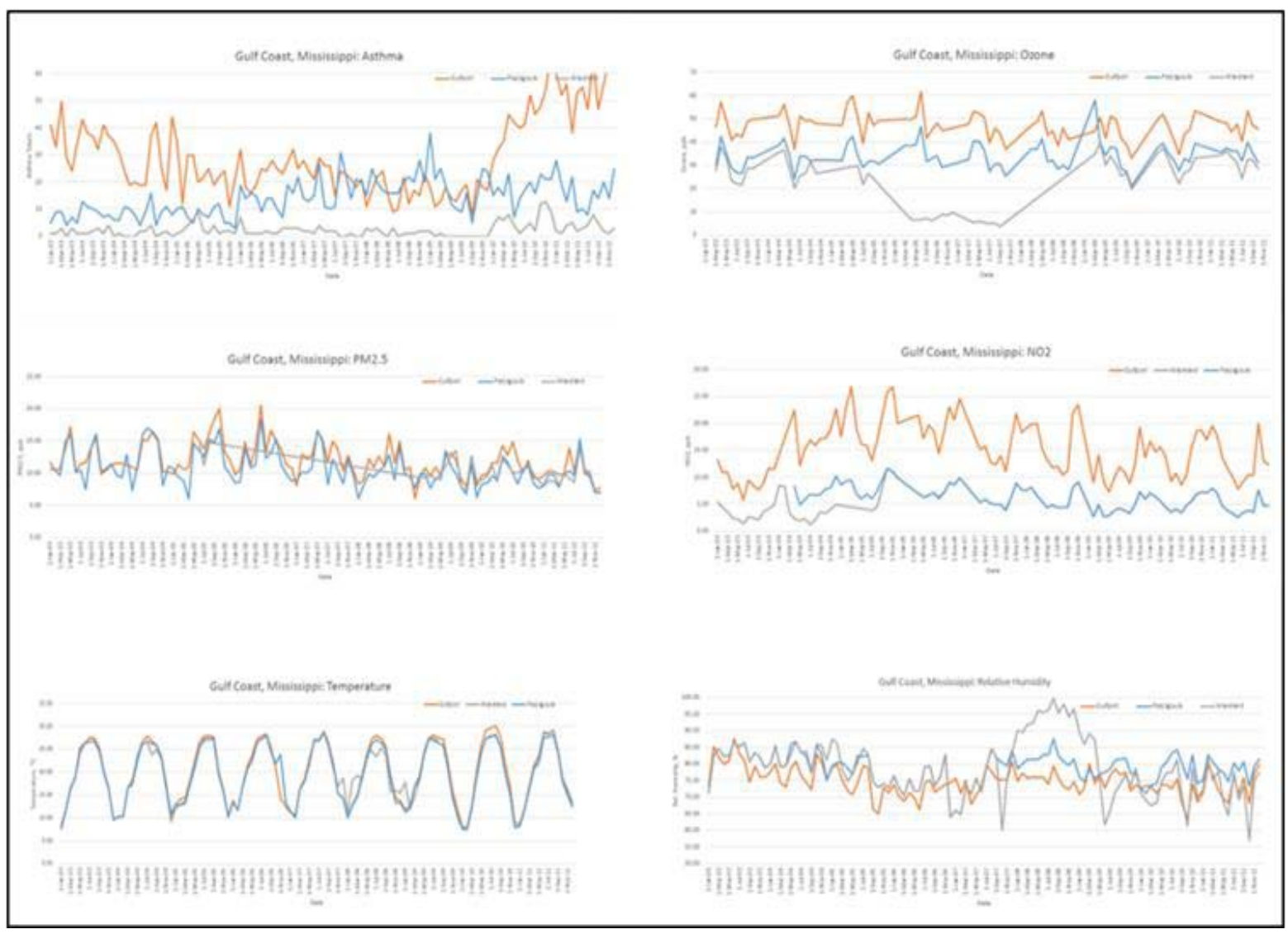

Figure 2: Time series of asthma, $\mathrm{PM}_{2.5}$, Ozone, $\mathrm{NO}_{2}$, Temperature, and Humidity of data of Mississippi Gulf Coast regions during the period of 2003 to 2011.

$$
\begin{aligned}
& \log \left(\mu_{t}\right)=\beta_{0}+\beta_{1} P M_{2.5} \\
& \log \left(\mu_{t}\right)=\beta_{0}+\beta_{4} \text { temperature }+\beta_{5} \text { Humidity }
\end{aligned}
$$

\section{Study area}

The locations considered for the study are Gulfport in Harrison county, Pascagoula in Jackson county, and Waveland in Hancock county. The three counties are adjacent to the Mississippi Gulf Coast and are strategically located in the Coast (See Figure 1 and Figure 2) $[14,15]$. The objective in choosing each of these locations in their respective county is because of the possibility of correlating the asthma prevalence of the local area to the corresponding air quality data, and meteorological data. The population of the Mississippi Gulf Coast appears to be growing and is projected to increase because of the demand for job employment in the casinos, aerospace and defense industries in addition to job opportunities in the oil \& gas industries, power plants, and construction. Based on the US Census Bureau estimate, the population of the three cities to the corresponding county of Gulfport/Harrison, Pascagoula/Jackson, and Waveland/ Hancock are respectively 69,220/194,029, 22,429/140,298, and $6541 / 45,255$ [16]. MS Department of Health Report reports adult asthma prevalence of $7.2 \%$ for the health district of these counties [17].

\section{Asthma data}

Asthma admission data in Gulfort, Pascagoula, and Waveland for the period 2003 to 2011 is obtained upon request from Mississippi Department of Health [18]. The raw data was reconstructed into county wise and extracted for the three locations of interest for the present study.

\section{Air pollutant data}

Air quality data for Gulfport, Pascagoula, and Waveland is obtained from two sources-Air Quality Division of Mississippi 
Table 1: Descriptive Statistics of the cause variables of Mississippi Gulf Coast Region.

\begin{tabular}{|c|c|c|c|c|c|c|}
\hline Region: Gulfport & $\mathrm{N}$ & Minimum & Maximum & Mean & Std. Dev & Variance \\
\hline Asthma & 2953 & 0 & 9 & 0.95 & 1.112 & 1.235 \\
\hline $\mathrm{PM}_{2.5}\left(\mu \mathrm{g} / \mathrm{m}^{3}\right)$ & 2730 & 0.6 & 52.2 & 12.242 & 5.906 & 34.878 \\
\hline Ozone (ppb) & 2102 & 15 & 98 & 40.097 & 14.07 & 197.99 \\
\hline $\mathrm{NO}_{2}\left(\mu \mathrm{g} / \mathrm{m}^{3}\right)$ & 2530 & 0.7 & 73 & 14.746 & 9.059 & 82.06 \\
\hline Temperature $\left({ }^{\circ} \mathrm{C}\right)$ & 2944 & -2 & 33 & 20.798 & 7.187 & 51.67 \\
\hline Humidity (\%) & 2944 & 33 & 99 & 74.511 & 11.356 & 128.96 \\
\hline Valid N (list-wise) & 1835 & & & & & \\
\hline Region: Ascagoula & $\mathrm{N}$ & Minimum & Maximum & Mean & Std. Dev & Variance \\
\hline Asthma & 3287 & 0 & 7 & 0.47 & 0.732 & 0.536 \\
\hline $\mathrm{PM}_{2.5}\left(\mu \mathrm{g} / \mathrm{m}^{3}\right)$ & 1003 & 2 & 42 & 10.84 & 5.454 & 29.746 \\
\hline Ozone (ppb) & 2115 & 11 & 96 & 45.51 & 13.965 & 195.021 \\
\hline $\mathrm{NO}_{2}\left(\mu \mathrm{g} / \mathrm{m}^{3}\right)$ & 2477 & 0 & 34 & 6.15 & 3.514 & 12.348 \\
\hline Temperature $\left({ }^{\circ} \mathrm{C}\right)$ & 3128 & -17.8 & 36.7 & 19.652 & 7.8834 & 62.148 \\
\hline Humidity (\%) & 3287 & 0 & 100 & 74.673 & 20.3276 & 413.211 \\
\hline Valid N (listwise) & 518 & & & & & \\
\hline Region:Waveland & $\mathrm{N}$ & Minimum & Maximum & Mean & Std. Dev & Variance \\
\hline Asthma & 3287 & 0 & 4 & 0.075 & 0.3034 & 0.092 \\
\hline $\mathrm{PM}_{2.5}\left(\mu \mathrm{g} / \mathrm{m}^{3}\right)$ & 1497 & 0 & 41 & 5.226 & 6.3599 & 40.448 \\
\hline Ozone (ppb) & 1406 & 0 & 74.5 & 29.821 & 10.1235 & 102.485 \\
\hline $\mathrm{NO} 2\left(\mu \mathrm{g} / \mathrm{m}^{3}\right)$ & 808 & 0 & 19.8 & 3.644 & 2.4249 & 5.88 \\
\hline Temperature $\left({ }^{\circ} \mathrm{C}\right)$ & 1420 & -17.8 & 32.2 & 19.621 & 7.8524 & 61.66 \\
\hline Humidity (\%) & 1606 & 0 & 100 & 77.523 & 15.668 & 245.486 \\
\hline
\end{tabular}

Table 2: Correlations among the data variables of Mississippi Gulf Coast Region.

\begin{tabular}{|c|c|c|c|c|c|c|c|}
\hline \multicolumn{8}{|c|}{ Gulfport: } \\
\hline & & Asthma & $\mathrm{PM}_{2.5}$ & Ozone & $\mathrm{NO}_{2}$ & Temperature & Humidity \\
\hline \multirow{2}{*}{ Asthma } & $\begin{array}{l}\text { Pearson } \\
\text { Correlation }\end{array}$ & 1 & $-.038^{\star}$ & 0.041 & 0.024 & $-.072^{* *}$ & $-.038^{*}$ \\
\hline & $\mathrm{N}$ & 3287 & 3051 & 2102 & 2791 & 3278 & 3278 \\
\hline \multicolumn{8}{|c|}{ Pascagoula: } \\
\hline & & Asthma & $\mathrm{PM}_{2.5}$ & Ozone & $\mathrm{NO}_{2}$ & Temperature & Humidity \\
\hline \multirow{2}{*}{ Asthma } & $\begin{array}{c}\text { Pearson } \\
\text { Correlation }\end{array}$ & 1 & 0.007 & -0.014 & -0.007 & $-.094^{* *}$ & -0.006 \\
\hline & $\mathrm{N}$ & 3287 & 1003 & 2115 & 2477 & 3128 & 3287 \\
\hline \multicolumn{8}{|c|}{ Waveland: } \\
\hline & & Asthma & $\mathrm{PM}_{2.5}$ & Ozone & $\mathrm{NO}_{2}$ & Temperature & Humidity \\
\hline \multirow[t]{2}{*}{ Asthma } & $\begin{array}{c}\text { Pearson } \\
\text { Correlation }\end{array}$ & 1 & $-.056^{\star}$ & -0.004 & -0.016 & -0.02 & $-.052^{*}$ \\
\hline & $\mathrm{N}$ & 3287 & 1497 & 1406 & 808 & 1420 & 1606 \\
\hline
\end{tabular}

${ }^{* *}$ Correlation is significant at the 0.01 level (2-tailed).

${ }^{*}$ Correlation is significant at the 0.05 level (2-tailed).

Department of Environmental Quality [19] and from U.S. EPA's Environmental Protection Agency (U.S. EPA) air quality system data mart [20]. For the purpose of present study three criteria air pollutant parameters were selected, namely Particulate Matter of diameter less than 2.5 microns $\left(\mathrm{PM}_{2.5}\right)$, Ozone $\left(\mathrm{O}_{3}\right)$, and Nitrogen dioxide $\left(\mathrm{NO}_{2}\right)$ and the daily concentrations were obtained during the period 2003 to 2011 .

\section{Meteorological data}

The daily temperature and humidity data of Gulfport, Pascagoula, and Waveland are obtained for the period 2003 to 2011 from Weather Underground web source [21].

\section{Results and Discussion}

The descriptive statistics of asthma admissions, the air pollutants, 
Table 3: Poisson Regression Model for increase in asthma for a unit increase in the predictor variable. Excluded represents missing data out of the total sample size of 3287; *denotes Statistically Significant.

\begin{tabular}{|c|c|c|c|c|c|c|}
\hline \multirow[b]{2}{*}{ Gulfport } & \multirow[t]{2}{*}{ Excluded } & \multirow[t]{2}{*}{$\beta$} & \multirow[t]{2}{*}{$\mathrm{p}$ value } & \multirow[t]{2}{*}{$\exp (\beta)$} & \multicolumn{2}{|c|}{$95 \%$ Wald Confidence Interval for $\exp (\beta)$} \\
\hline & & & & & Lower & Upper \\
\hline PM & 246 & -0.0083 & $0.049^{*}$ & 0.992 & 0.985 & 1 \\
\hline $\mathrm{O}_{3}$ & 1186 & 0.003 & $0.044^{*}$ & 1.003 & 1 & 1.007 \\
\hline $\mathrm{NO}_{2}$ & 497 & 0.003 & 0.279 & 1.003 & 0.998 & 1.008 \\
\hline Temperature & 0 & -0.01 & $0.00^{*}$ & 0.99 & 0.994 & 1.001 \\
\hline Humidity & 0 & -0.002 & 0.229 & 0.998 & 0.994 & 1.001 \\
\hline \multicolumn{7}{|l|}{ Pascagoula } \\
\hline PM & 2284 & 0.002 & 0.815 & 1.002 & 0.986 & 1.018 \\
\hline $\mathrm{O}_{3}$ & 1172 & -0.002 & 0.51 & 0.998 & 0.994 & 1.003 \\
\hline $\mathrm{NO}_{2}$ & 810 & -0.003 & 0.721 & 0.997 & 0.981 & 1.013 \\
\hline Temperature & 159 & -0.021 & $0.00^{*}$ & 0.979 & 0.972 & 0.986 \\
\hline Humidity & 159 & 0.004 & 0.07 & 1.004 & 1 & 1.009 \\
\hline \multicolumn{7}{|l|}{ Waveland } \\
\hline PM & 1790 & -0.039 & $0.012^{*}$ & 0.962 & 0.933 & 0.991 \\
\hline $\mathrm{O}_{3}$ & 1887 & -0.002 & 0.85 & 0.998 & 0.981 & 1.015 \\
\hline $\mathrm{NO}_{2}$ & 2479 & -0.03 & 0.654 & 0.97 & 0.852 & 1.105 \\
\hline Temperature & 1867 & -0.007 & 0.493 & 0.993 & 0.973 & 1.013 \\
\hline Humidity & 1867 & -0.007 & 0.177 & 0.993 & 0.983 & 1.003 \\
\hline
\end{tabular}
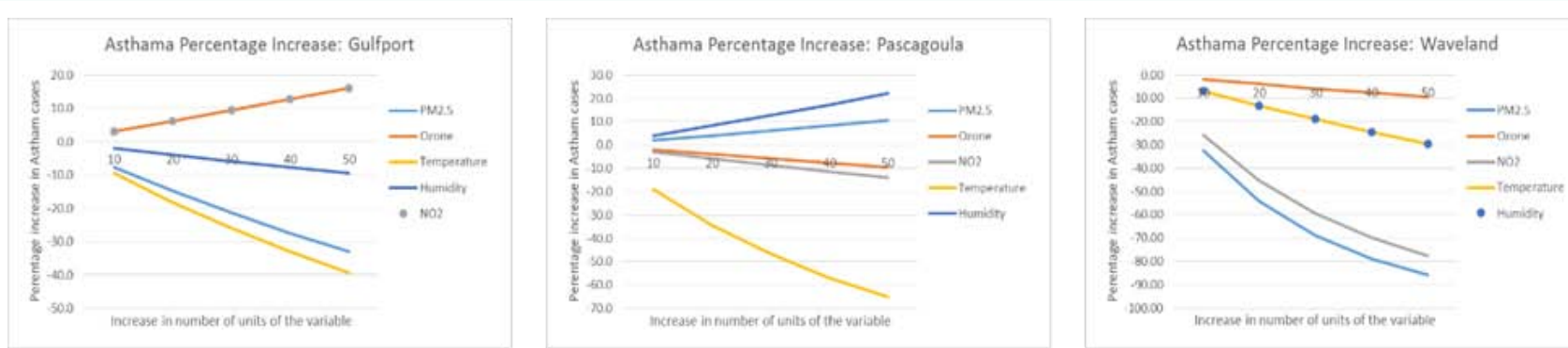

Figure 3: Asthma Projection with increase in the cause variables (by 10 units) for the regions of Gulfport, Pascagoula, and Waveland in the Mississippi Gulf Coast based on the data during the period 2003 to 2011.

and the meteorological variables is shown in Table 1.

During the period between 2003 and 2011 and for the case of Gulfport region, the minimum monthly average concentrations of asthma total admissions, $\mathrm{PM}_{2.5}$, Ozone, $\mathrm{NO}_{2}$, Temperature, and Humidity are $0,0.6 \mu \mathrm{g} / \mathrm{m}^{3}, 15 \mathrm{ppb}, 0.7 \mu \mathrm{g} / \mathrm{m}^{3},-2^{0} \mathrm{C}$, and $33 \%$ respectively. Similarly, the corresponding maximum average concentrations are $9,52.2 \mu \mathrm{g} / \mathrm{m}^{3}, 98 \mathrm{ppb}, 73 \mu \mathrm{g} / \mathrm{m}^{3}, 33^{\circ} \mathrm{C}$, and 99\% respectively. For the case of Pascagoula region, the minimum monthly average concentrations of asthma total admissions, $\mathrm{PM}_{2.5}$, Ozone, $\mathrm{NO}_{2}$, Temperature, and Humidity are $0,2 \mu \mathrm{g} / \mathrm{m}^{3}, 11 \mathrm{ppb}, 0 \mu \mathrm{g} /$ $\mathrm{m}^{3},-17.8^{\circ} \mathrm{C}$, and $0 \%$ respectively; and the corresponding maximum average concentrations are $7,42 \mu \mathrm{g} / \mathrm{m}^{3}, 96 \mathrm{ppb}, 34 \mu \mathrm{g} / \mathrm{m} 3,36.7^{\circ} \mathrm{C}$, and $100 \%$ respectively. For the case of Waveland region, the minimum average concentrations of asthma total admissions, $\mathrm{PM}_{25}$, Ozone, $\mathrm{NO}_{2}$, Temperature, and Humidity are $0,0 \mu \mathrm{g} / \mathrm{m}^{3}, 0 \mathrm{ppb}, 0 \mu \mathrm{g} / \mathrm{m}^{3}$, $-17.8^{\circ} \mathrm{C}$, and $0 \%$ respectively; and the corresponding maximum average concentrations are $4,41 \mu \mathrm{g} / \mathrm{m}^{3}, 74.5 \mathrm{ppb}, 19.8 \mu \mathrm{g} / \mathrm{m}^{3}, 32.2^{\circ} \mathrm{C}$, and $100 \%$ respectively.
The correlation among the data variables is shown in Table 2. There is a negative correlation between asthma and $\mathrm{PM}_{2.5}$ and is statistically significant $(\mathrm{p}<0.05)$ for the Gulfport and Waveland regions. Ozone shows positive correlation for Gulfport region, while the other two regions show negative correlation, but in either case the correlation is not statistically significant. As expected, the temperature and humidity show negative correlations in all the three regions, and is statistically significant in many instances.

The Poisson Regression Model analysis was conducted in zero lag condition for each of the regions of the study and the results are given in Table 3. The association between asthma and $\mathrm{PM}_{2.5}$ appears to be negative and statistically significant for the Gulfport and Waveland regions while it is positive and not statistically significant for the Pascagoula region. The association between asthma and $\mathrm{O}_{3}$ is positive and statistically significant, but for the other two regions it is negative and not statistically significant. The association between asthma and $\mathrm{NO}_{2}$ is not statistically significant in all the three regions and shows positive for the Gulfport region only. The association of asthma with 
temperature is negative and statistically significant in most of the cases but the association with humidity though negative in many cases and is not statistically significant in all the cases. In all the cases the association for $\mathrm{NO}_{2}$ is not statistically significant mostly because of the limited data availability compared to the rest of the variables of study.

Using the values of the log linear regression coefficients $(\beta)$, percent increase of asthma of the residents is projected for a stepwise increment of 10 units in each of the causing variables for each of the region, and the projected plots are shown in Figure 3. Considering the statistically significant situations, for the region of Gulfport an increase of PM from zero by $10 \mu \mathrm{g} / \mathrm{m}^{3}$ projects a decrease in asthma cases by about 8 , while an increase of $\mathrm{O}_{3}$ by $10 \mathrm{ppb}$ results in an increase of asthma by 3 . In the region of Waveland, the model predicts a decrease in asthma by about 32 by an increase of PM from by $10 \mu \mathrm{g} / \mathrm{m}^{3}$.

The results of the present study though providing a basic understanding of the association of the air pollutants and asthma in the Mississippi Gulf Coast region, is limited by many factors such as the pollutant and meteorological data availability, socio-economic factors, indoor or background pollution, and population migration. The number of variables used in the Poisson distribution model is rather small and widely varying among the regions of study Gulfport (1835), Pascagoula (518), and Waveland (42). In general, the Poisson distribution model does require a large data set [22] for obtaining significant results and their consistency among other regions. Additionally, the mechanisms of specific air pollutants on various respiratory disorders is not clear [23,24], while some investigations considered air pollutants as the cause for asthma that can lead to severe respiratory disorders. Chan et al. [25] have shown positive impact of PM10 on asthma outpatient and emergency settings. In our earlier study [26], we also observed that $\mathrm{PM}_{2.5}$ might have positive correlation in the increase of asthma rate in New York State. However, Nawahda [27] study shows that increased levels of $\mathrm{PM}_{2.5}$ and surface ozone in Japan is not significantly contributing to increased asthma prevalence among the school children to assume for a strong association. But, a controlled laboratory study [28] do show that ozone positively aggravates asthma. The literature survey warrants more critical investigations for understanding the association between asthma and specific pollutants. Hence, the results of the present study may be considered as a rapid and easy evaluation of the data to obtaining first order effects and may not be considered as reflecting exact association.

\section{Conclusion}

The present work shows a comparative study of Poisson Regression Model to finding association between asthma with criteria pollutants and weather parameters over three locations in the Mississippi Gulf coast, namely Gulfport, Pascagoula, and Waveland during the period 2003 to 2011. The regions are considered because of the availability of the data to study the influence of industrial growth and unpredictable weather patterns on the asthma of the residents. The air pollutants considered are Particulate Matter of diameter less than 2.5 microns $\left(\mathrm{PM}_{2.5}\right)$, Ozone $\left(\mathrm{O}_{3}\right)$, and Nitrogen Oxide $\left(\mathrm{NO}_{2}\right)$; while the meteorological parameters considered are temperature, and humidity. Considering the statistically significant situations, the association between asthma and $\mathrm{PM}_{2.5}$ appears to be negative for the Gulfport and Waveland regions, while it is positive association between asthma and $\mathrm{O}_{3}$ for the Gulfport region. As expected, a negative association is observed between asthma and temperature in most of the cases. The association with humidity though negative in many cases and is not statistically significant in all the cases. In all the cases the association for $\mathrm{NO}_{2}$ is not statistically significant mostly because of the limited data availability compared to the rest of the variables of study. The results are limited by the full availability of data for the corresponding variables, and also by the influence of other factors such as indoor environment and demographics which are not considered in the present study. In view of the limitations, the results of the present study may be considered as a rapid and easy evaluation of the data to obtaining first order effects of air pollutants and asthma in the Mississippi Gulf Coast region, and may not be considered as reflecting exact association. However, the Poisson Regression Model facilitates studying the association of asthma for mitigating and making policy decisions for controlling its prevalence.

\section{References}

1. Levin I, Burkhart K, Metzger L, Smith S. Breakdowns in Air Quality. Air Pollution from Industrial Malfunctions and Maintenance in Texas. EIP Report. 2016.

2. Yerramilli A, Dodla VBR, Challa VS, Myles L, Pendergrass WR, Vogel CS et al. An integrated WRF/HYSPLIT modeling approach for the assessment of PM2.5 source regions over the Mississippi Gulf Coast region. Air Qual Atmos Health. 2012; 5: 401-412.

3. Yerramilli A, Challa VS, Dodla VBR, Myles L, Pendergrass WR, Vogel CS, et al. Simulation of surface ozone pollution in the Central Gulf Coast region during summer synoptic condition using WRF/Chem air quality model. Atmospheric Pollution Research. 2012; 3: 55-71.

4. Bruce N, Perez-Padilla R, Albalak R. Indoor air pollution in developing countries: a major environmental and public health challenge. Bull World Health Organ. 2000; 78: 1078-1092.

5. Smith KR, Samet JM, Romieu I, Bruce N. Indoor air pollution in developing countries and acute lower respiratory infections in children. Thorax. 2000; 55: 518-532.

6. Analitis A, Katsouyanni K, Dimakopoulou K, Samoli E, Nikoloulopoulos AK Petasakis $\mathrm{Y}$, et.al. Short-term effects of ambient particles on cardiovascular and respiratory mortality. Epidemiology. 2006; 17: 230-233.

7. Hsieh YL, Yang YH, Wu TN, Yang CY. Air pollution and hospital admissions for myocardial infarction in a subtropical city: Taipei, Taiwan. J. Toxicol. Environ. Health. Pt. A. 2010; 73:757-765.

8. Levy J.I, Hammitt JK, Spengler JD. Estimating the mortality impacts of particulate matter: What can be learned from between-study variability? Environ. Health Perspect. 2000; 108: 109-117.

9. Pope CA 3rd, Burnett RT, Thurston GD, Thun MJ, Calle EE, Krewski D, et al. Cardiovascular mortality and long-term exposure to particulate air pollution: Epidemiological evidence of general pathophysiological pathways of disease. Circulation 2004, 109, 71-77.

10. Amit KG, Tuluri F, Tchounwou PB. A GIS Based Approach for Assessing the Association between Air Pollution and Asthma in New York State, USA. Int J Environ Res Public Health. 2014; 11: 4845-4869.

11. Amit KG, Ashok KP, Tchounwou PB, Tuluri, F. Analyzing the Role of Air Pollution And Meteorology on Asthma Prevalence Using A Poisson Regression Model: A Case Study Of Gulfport Region, Mississippi, USA. Int Symposium on Env Res Pub Health. Jackson, 2016.

12. Muriel-Garcia1 M, Cerón-Bretón R, Cerón-Bretón JG. Air Pollution in the Gulf of Mexico. Open Journal of Ecology. 2016; 6: 32-46.

13. de Souza1A, Kofanovski AZ, Sabbah I, da Silva Santos DA. Asthma and 
Environmental Indicators: A Time-series Study. J Allergy Ther. 2016: 7: 1.

14. Mississippi Gulf Coast Image.

15. Air Quality Monitors along Mississippi Gulf Coast.

16. Boykins T. National Cancer Health Disparities Geographic Intervention Project, Mississippi Gulf Coast Community Portrait, Final Report, 2013.

17. Zhnag L. The Burden of Asthma in Mississippi: 2014 Asthma Surveillance Summary Report. MS Asthma Surveillance Report, 2014.

18. Mississippi Healthcare Cost and Utilization Project (HCUP).

19. Mississippi Department of Environmental Quality Division (MSDEQ).

20. US EPA.

21. US Weather Ground.

22. Selvin, S. Statistical Analysis of Epidemiologic Data (Monographs in Epidemiology and Biostatistics). Oxford University Press. 2004; 263-283.
23. Brunekreef B, Dockery DW, Krzyzanowski M. Epidemiologic studies on shortterm effects of low levels of major ambient air pollution components. Environ Health Perspect. 1995; 103: 3-13.

24. Delfino RJ, Coate BD, Zeiger RS, Seltzer JM, Street DH, Koutrakis P. Daily asthma severity in relation to personal ozone exposures and outdoor fungal spores. Am J Respir Crit Care Med. 1996; 154, 633-641.

25. Chan T, Chen M, Lin I, Lee C, Chiang P, Wang D, et al. Spatiotemporal analysis of air pollution and asthma patient visits in Taipei, Taiwan. Int. J. Health Geogr. 2009; 8: 26.

26. Gorai AK, Tuluri F, Tchounwou PB. A GIS Based Approach for Assessing the Association between Air Pollution and Asthma in New York State, USA. Int J Environ Res Public Health. 2014; 11: 4845-4869.

27. Nawahda A. The association of PM2.5 and surface ozone with asthma prevalence among school children in Japan: 2006-2009. Health 2013; 5: 1-7.

28. Koenig JQ. Effect of Ozone on respiratory responses in subjects with asthma. Environ. Health Perspect. 1995; 103: 103-105.
Austin J Allergy - Volume 4 Issue 1 - 2017

Submit your Manuscript | www.austinpublishinggroup.com

Tuluri et al. (C) All rights are reserved
Citation: Tuluri F and Gorai AK. Asthma Trends in Mississippi Coastal Region with Air Pollutants and Meteorological Factors. Austin J Allergy. 2017; 4(1): 1026. 